\title{
An Empirical Study of Asymmetric Pricing in Retail Gasoline and Diesel Markets in Taiwan, Japan, South Korea, and Singapore
}

\author{
Kuo-Wei Chou ${ }^{1}$, Chin-Yuen Chang ${ }^{1} \&$ Fei Hu${ }^{1}$ \\ ${ }^{1}$ School of Applied Economics, Fo Guang University, Yilan, Taiwan \\ Correspondence: Kuo-Wei Chou, School of Applied Economics, Fo Guang University, 160 Linwei Road, Jiaosi, \\ Yilan 26247, Taiwan. Tel: 886-3-987-1000 ext 23517. E-mail: kwchou@mail.fgu.edu.tw
}

Received: April 19, 2013

Accepted: May 14, 2013

Online Published: June 24, 2013

doi:10.5430/ijfr.v4n3p35

URL: http://dx.doi.org/10.5430/ijfr.v4n3p35

\begin{abstract}
This study estimated retail price adjustments in the gasoline and diesel markets of Taiwan, Japan, South Korea, and Singapore using monthly data between 2004M1 and 2012M6. An asymmetric error correction model (ECM) was employed as a framework and the results showed that asymmetric adjustments in retail gasoline and diesel prices are common, and that the adjustments, which quickly and obviously responded to cost reductions, are a type of politico-economic asymmetry. This finding differs from the results of numerous international studies. In other words, although gasoline and diesel markets are evident oligopolies, the government's intervention behavior appears to control the gasoline and diesel price adjustments of the 4 East Asian countries evaluated in this study (i.e., Taiwan, Japan, South Korea, and Singapore).
\end{abstract}

Keywords: crude oil price, retail gasoline price, retail diesel price, price asymmetry, politico-economic asymmetry

\section{Introduction}

Gasoline and diesel are the main sources of fuel required for modern life and transportation, and the adjustment of gasoline and diesel prices has become a major public issue. The drastic fluctuations in recent international oil prices have affected retail gasoline and diesel prices in various countries and prompted public opinion and academia to question the pricing behaviors of oil companies. Galeotti, Lanza, \& Manera (2003) stated that because of the strong dependence of people on mobility made possible by vehicles, the public is highly sensitive to changes in gasoline and diesel prices. A majority of people believe that increases in oil prices are rapidly reflected in increased gasoline and diesel prices, whereas declines in oil prices are only slowly mirrored in decreasing gasoline and diesel prices. Economists compare this price asymmetry to "rockets and feathers" (Bachmeier \& Griffin, 2003; Bacon, 1991; Borenstein, Cameron, \& Gilbert, 1997; Godby, Lintner, \& Wandschneider, 2000; Johnson, 2002; Manning, 1991; Radchenko, 2005; Radchenko \& Shapiro, 2011).

Price asymmetry indicates various levels of adjustment to gasoline and diesel prices in response to positive and negative cost impacts, and demonstrates the rigidity of price adjustments; that is, changes in oil prices are not immediately and completely transmitted to gasoline and diesel prices. Because in an oligopoly, such as the gasoline and diesel market, the market is controlled by a small number of players, numerous studies have attributed gasoline and diesel price asymmetry to the collusive behavior of retailers or governments. When the cost of crude oil decreases, merchants or sellers in an oligopoly tend to collude to maintain (and not reduce) the retail prices to increase retail profits. However, when the cost of crude oil increases, retailers in an oligopoly immediately increase prices to prevent their profits from dropping. The collusive behavior of retailers in an oligopoly causes gasoline and diesel prices to show an adjustment pattern of rapid increase and slow decrease in response to changing oil prices (Al-Gudhea, Kenc, \& Dibooglu, 2007; Borenstein et al., 1997; Chen, Finney, \& Lai, 2005; Radchenko, 2005; Verlinda, 2008).

Nevertheless, gasoline and diesel are crucial products to society. To protect domestic gasoline and diesel prices from the excessive intervention of international crude oil markets, governments often intervene to stabilize prices (Chou, 2012; Karrenbrock, 1991; Tappata, 2009; Wu, Huang, \& Liu, 2011). In addition, Kirchgassner \& Kubler (1992) indicated that when the cost of crude oil increases, retailers are hesitant and become unwilling to rapidly increase prices because they might be accused of abusing their market power and consumer price gouging. However, similar motives do not exist when crude oil costs decline. Consequently, government intervention or the responses of 
retailers to politics cause a trend of rapid decreases and slow increases in prices when oil prices change. Kirchgassner \& Kubler (1992) referred this type of price asymmetry as "politico-economic asymmetry".

Price asymmetry and imperfect or incomplete pricing can be empirically investigated based on two dimensions, that is, the adjustment level and path of retail prices in response to positive and negative oil price impacts. In this study, data from Taiwan, Japan, South Korea, and Singapore (sample interval: 2004M1 to 2012M6) were used, and an asymmetric error correction model (asymmetric ECM) was employed to estimate the effects of positive and negative oil price impacts on retail gasoline and diesel prices. The results of estimations regarding long-term adjustment coefficients showed that gasoline and diesel retailers, who engage in imperfect competition, raised prices more rapidly when the prices were excessively low. However, short-term increases in oil prices did not more significantly increase retail gasoline and diesel prices. The results of a price asymmetry test showed that price asymmetry is common. Furthermore, the majority of the price adjustment paths were inconsistent with the "rockets and feathers" trend advocated by several previous studies; rather, they were more consistent with the politico-economic asymmetry proposed by Kirchgassner and Kubler (1992), which was possibly caused by government intervention behavior.

The analytical framework of this study is as follows: Section 2 introduces the empirical model used in this study. Section 3 describes the data sources and characteristics. Section 4 summarizes the relevant empirical results and offers a discussion. Section 5 provides concluding remarks.

\section{The Model}

If gasoline and diesel prices as well as cost variables are first-order integrated variables and cointegration exists, then dynamic price adjustments can be represented using error correction form. ECM is a standard method employed for investigating dynamic price adjustments (Bachmeier \& Griffin, 2003; Bettendorf, van der Geest, \& Varkevisser, 2003), and it links the cointegrated series of long-term equilibrium and short-term dynamic relationships. The long-term equilibrium between gasoline (diesel) prices and oil prices can be written as follows:

$$
r_{t}=\delta_{o}+\delta_{1} o_{t}+u_{t}
$$

where $r_{t}$ is the retail gasoline (diesel) price. In addition, in countries that do not use the U.S. dollar, the cost to refine oil into gasoline or diesel must be expressed using domestic currencies. Therefore, $o_{t}$ represents oil prices in various domestic currencies; $r_{t}$ and $o_{t}$ are both expressed using natural logarithmic forms. Furthermore, $u_{t}$ is the error term. $\delta_{1}$ measures the degree of the long-term pass-through of oil to gasoline (diesel) prices. $\delta_{o}$ represents additional retail costs, such as labor, rent, and retail taxes. Equation (1) shows the equilibrium relationship between the price and cost. In circumstances in which stable industrial structures exist, changes in costs do not affect the equilibrium relationship (Johnson, 2002). Subsequently, the ordinary least squares (OLS) method was employed to obtain superconsistent coefficient estimates.

If the price in Equation (1) is I(1) and it has a cointegration relationship, the error-corrected price dynamics are:

$$
\Delta r_{t}=\alpha_{0}+\sum_{i=1}^{m} \alpha_{i} \Delta r_{t-i}+\sum_{i=0}^{n} \beta_{i} \Delta o_{t-i}+\theta z_{t-1}+\varepsilon_{t}
$$

$\Delta$ denotes the first difference, and $\varepsilon_{t}$ is the error term. $\beta_{i}$ measures the short-term impacts of oil price change, in which $\beta_{0}$ is the immediate effect of oil price changes, and $\beta_{i} \forall i=1, \cdots, n$ represents the distributed lag effects of oil price changes (Frey \& Manera, 2007). In addition, $\alpha_{i}$ measures the persistency of gasoline (diesel) price changes, $z$ is the error correction term $\left(z_{t-1}=r_{t-1}-\delta_{0}-\delta_{1} o_{t-1}\right)$, and $\theta$ denotes the adjustment coefficient.

To investigate the asymmetric responses of short-term prices, the basic ECM was extended into an asymmetric ECM (Granger \& Lee, 1989):

$$
\Delta r_{t}=\alpha_{0}+\sum_{i=1}^{m} \alpha_{i}^{+} \Delta r_{t-i}^{+}+\sum_{i=1}^{m} \alpha_{i}^{-} \Delta r_{t-i}^{-}+\sum_{i=0}^{n} \beta_{i}^{+} \Delta o_{t-i}^{+}+\sum_{i=0}^{n} \beta_{i}^{-} \Delta o_{t-i}^{-}+\theta^{+} z_{t-1}^{+}+\theta^{-} z_{t-1}^{-}+\varepsilon_{t}
$$

in which gasoline (diesel) price change, oil price change, and the error correction term were divided into positive and negative portions. The variables were defined as follows: $\Delta r_{t}^{+}=\max \left\{\Delta r_{t}, 0\right\}, \Delta r_{t}^{-}=\min \left\{\Delta r_{t}, 0\right\}$, $\Delta o_{t}^{+}=\max \left\{\Delta o_{t}, 0\right\}, \Delta o_{t}^{-}=\min \left\{\Delta o_{t}, 0\right\}, z_{t}^{+}=\max \left\{z_{t}, 0\right\}$, and $z_{t}^{-}=\min \left\{z_{t}, 0\right\}$. Equation (3) maintains the essence of the ECM but enables gasoline (diesel) prices to respond to impacts from oil prices in a more flexible manner. In particular, $\beta_{0}^{+}$and $\beta_{0}^{-}$are the immediate effects of positive and negative oil price impacts, respectively, and $\sum_{i=0}^{n} \beta_{i}^{+}$and $\sum_{i=0}^{n} \beta_{i}^{-}$respectively measure the cumulated impacts of positive and negative oil price effects. In addition, $\alpha_{i}^{+}$and $\alpha_{i}^{-}$are the autoregressive distributed lag effects of $\Delta r_{t}^{+}$and $\Delta r_{t}^{-}$, respectively, and $\theta^{+}$and $\theta^{-}$ measure the rates of convergence to equilibrium when prices are higher or lower than the equilibrium level.

\section{Data Sources and Characteristics}

The monthly data examined in this study were selected from Taiwan, Japan, South Korea, and Singapore between 
2004M1 and 2012M6. Variable $o_{t}$ is a proxy for the average international oil price (i.e., the mean price of Dubai Crude, Brent Crude, and West Texas Intermediate oil types) and was converted into various prices in domestic currencies based on the exchange rates. Regarding retail gasoline and diesel prices, Radchenko (2005) indicated that overlooking tax system amendments during the sample period may result in estimation difficulties. Johnson (2002) also believed that tax system adjustments may cause changes in the data structure, yielding spurious relationships. Consequently, $r_{t}$ was defined as pre-tax gasoline and diesel prices. Limited by data acquisition, the gasoline in this study was RON 95 unleaded gasoline for Taiwan, South Korea, and Singapore, and RON 100 unleaded gasoline for Japan. The data were obtained from the website of the Bureau of Energy of Taiwan (http://www.moeaboe.gov.tw/oil102/), and the prices were calculated using the liter as a unit.

Determining whether a stable long-term relationship exists between $r_{t}$ and $o_{t}$ is required to conduct empirical estimations using Equations (1) and (3). If $r_{t}$ and $o_{t}$ are both $\mathrm{I}(1)$ and have a cointegration relationship, this implies that the variables include long-term equilibrium relationships and that an ECM can be developed (Engle \& Granger, 1987). In this study, an augmented Dicky-Fuller (ADF) test (including the intercept and time trend) was performed. The results indicated that none of the variables could reject the null hypothesis, which contended that the unit root existed. After taking the first-order difference of the variables, the same testing procedure was used, and the results showed that all variables significantly rejected the null hypothesis regarding the existence of unit roots, indicating that $r_{t}$ and $o_{t}$ are a I(1) series (the unit root test results are shown in Table 1).

Table 1. ADF tests

\begin{tabular}{lcc}
\hline Variables & Levels & First difference \\
\hline Oil prices $\left(\boldsymbol{o}_{\boldsymbol{t}}\right)$ & & \\
$\quad$ Taiwan & -0.416 & $-7.294^{* * *}$ \\
Japan & -0.281 & $-7.061^{* * *}$ \\
South Korea & -1.887 & $-8.263^{* * *}$ \\
$\quad$ Singapore & -2.048 & $-7.620^{* * *}$ \\
$\quad$ Retail gasoline prices $\left(\boldsymbol{r}_{\boldsymbol{t}}\right)$ & & \\
$\quad$ Taiwan & 0.594 & $-5.796^{* * *}$ \\
Japan & 0.278 & $-6.762^{* * *}$ \\
$\quad$ South Korea & 0.908 & $-7.093^{* * *}$ \\
Singapore & -1.730 & $-8.551^{* * *}$ \\
Retail diesel prices $\left(\boldsymbol{r}_{\boldsymbol{t}}\right)$ & & \\
$\quad$ Taiwan & -2.779 & $-9.285^{* * *}$ \\
Japan & -2.589 & $-7.389^{* * *}$ \\
$\quad$ South Korea & -2.940 & $-6.199 * * *$ \\
Singapore & -2.489 & $-10.765^{* * *}$ \\
\hline
\end{tabular}

1. The numbers in this table are the $t$ statistics of ADF regression, including both the intercept and time trend. The optimal lags of ADF regression that were determined using the Schwarz Criterion (maximum lags =12).

2. ***,**, and * indicate that the null hypothesis of a unit root is rejected at the $1 \%, 5 \%$, and $10 \%$ significance levels.

OLS was then employed to estimate Equation (1), and ADF tests (excluding the intercept and time trend) were performed on the residuals. The results are shown in Table 2. First, all regression residuals significantly rejected the unit-root null hypothesis at 5\% significance level, indicating a cointegration relationship between retail gasoline and diesel prices and oil prices in various countries. Estimation results for the cointegration relationship showed that oil prices generally had high long-term pass-through to diesel prices; only Singapore was an exception. For example, in Taiwan, a $1 \%$ oil price increase resulted in $0.606 \%$ and $0.800 \%$ long-term increases in the retail gasoline and diesel prices, respectively, possibly because differing gasoline and diesel refining processes caused different levels of dependence on crude oil. In addition, the $\delta_{0}$ estimation values for both gasoline and diesel prices were, in declining order, Japan, South Korea, Taiwan, and Singapore, indicating that retail gasoline (diesel) pricing in Japan is determined, to the highest degree among the four countries, by non-oil price costs, such as costs for labor, rent, and placement or allocation processes, whereas pricing in Singapore is the least so. 
Table 2. Cointegration relationships

\begin{tabular}{lccc}
\hline & $\delta_{0}$ & $\delta_{1}$ & Residuals ADF tests \\
\hline Retail gasoline prices & & & \\
Taiwan & $\left(0.344^{* * *}\right.$ & $0.606^{* * *}$ & $-4.593(0)^{* * *}$ \\
& $2.485^{* * *}$ & $(0.014)$ & \\
Japan & $(0.134)$ & $0.507^{* * *}$ & $-3.138^{* * *}$ \\
& $2.282^{* * *}$ & $(0.036)$ & $-2.904^{* *}$ \\
South Korea & $(0.173)$ & $0.711^{* * *}$ & \\
& $0.491^{* * *}$ & $0.028)$ & $-3.516^{* * *}$ \\
Singapore & $(0.018)$ & $(0.034)$ & \\
& & & $-4.924^{* * *}$ \\
Retail diesel prices & $0.885^{* * *}$ & $0.767^{* * *}$ & \\
Taiwan & $(0.051)$ & $(0.019)$ & $-3.037^{* * *}$ \\
& $2.205^{* * *}$ & $0.550^{* * *}$ & \\
Japan & $(0.136)$ & $(0.036)$ & $-4.391^{* * *}$ \\
South Korea & $2.137^{* * *}$ & $0.725^{* * *}$ & \\
Singapore & $(0.146)$ & $(0.023)$ & $-3.168^{* * *}$ \\
& $0.513^{* * *}$ & $0.791^{* * *}$ & $(0.042)$ \\
\end{tabular}

1. The number in (.) under the coefficient is the standard deviation. ${ }^{* *},{ }^{* *}$, and $*$ indicate that the coefficients are significant at the $1 \%, 5 \%$, and $10 \%$ levels.

2. The ADF test statistics ( $t$ statistics) for the residuals are computed from ADF regression without using the intercept and time trend. The optimal lags of ADF regression are determined using the Schwarz Criterion (maximum lags $=12) .{ }^{* * *},{ }^{* *}$, and $*$ indicate that the null hypothesis of a unit root is rejected at the $1 \%, 5 \%$, and $10 \%$ significance levels.

\section{The Estimation of Asymmetric ECM and Price Asymmetry}

Based on the previous analysis, an asymmetric ECM, as shown in Equation (3), was developed to represent the dynamic adjustments of gasoline (diesel) prices. Table 3 shows the estimation results of the coefficients in Equation (3); the standard deviations of the coefficients were heteroskedasticity and autocorrelation consistent (Newey \& West, 1987). The maximum lag was set at 12 (1 year), and the Schwarz criterion was employed to determine optimal lags $m$ and $n$ in Equation (3). For gasoline prices, the immediate effects of negative oil price impacts were more substantial. When the cumulated impacts of oil price effects were considered, gasoline prices did not respond more significantly to positive oil price impacts. By contrast, diesel prices had differing responses to positive and negative oil price impacts. For example, positive oil price impacts had greater immediate effects on the diesel prices in Japan and Singapore, whereas greater cumulated impacts occurred for South Korea. In addition, the estimation values of $\theta^{+}$and $\theta^{-}$were primarily negative, implying that prices were adjusted and converged to an equilibrium. The convergence rate was generally more rapid for negative imbalances in both gasoline and diesel prices, with the exceptions of the gasoline price in Singapore and the diesel price in South Korea, indicating that when prices are excessively low, gasoline and diesel retailers, who engage in imperfect competition, raise prices more rapidly. 
Table 3. Asymmetric error correction models

\begin{tabular}{|c|c|c|c|c|c|c|c|c|}
\hline & \multicolumn{2}{|c|}{ Retail gasoline prices } & \multicolumn{6}{|c|}{ Retail diesel prices } \\
\hline & Taiwan & Japan & $\begin{array}{l}\text { South } \\
\text { Korea }\end{array}$ & Singapore & Taiwan & & $\begin{array}{l}\text { South } \\
\text { Korea }\end{array}$ & Singapore \\
\hline$\alpha_{1}^{+}$ & $\begin{array}{c}0.302 * * \\
(0.121)\end{array}$ & $\begin{array}{c}0.401 * * * \\
(0.128)\end{array}$ & $\begin{array}{l}-0.140 \\
(0.121)\end{array}$ & $\begin{array}{l}-0.087 \\
(0.158)\end{array}$ & $\begin{array}{c}-0.619 * * \\
(0.263)\end{array}$ & $\begin{array}{c}0.475 * * * \\
(0.134)\end{array}$ & $\begin{array}{c}0.272 * * * \\
(0.100)\end{array}$ & $\begin{array}{l}-0.133 \\
(0.122)\end{array}$ \\
\hline$\alpha_{1}^{-}$ & $\begin{array}{c}0.071 \\
(0.138)\end{array}$ & $\begin{array}{l}-0.267 \\
(0.184)\end{array}$ & $\begin{array}{c}0.176 \\
(0.191)\end{array}$ & $\begin{array}{l}-0.068 \\
(0.194)\end{array}$ & $\begin{array}{c}0.026 \\
(0.110)\end{array}$ & $\begin{array}{l}-0.265 \\
(0.170)\end{array}$ & $\begin{array}{c}0.127 \\
(0.186)\end{array}$ & $\begin{array}{l}-0.489^{*} \\
(0.256)\end{array}$ \\
\hline$\alpha_{2}^{+}$ & & & & & & & & $\begin{array}{c}-0.154^{* *} \\
(0.075)\end{array}$ \\
\hline$\alpha_{2}^{-}$ & & & & & & & & $\begin{array}{c}-0.139 * * \\
(0.167)\end{array}$ \\
\hline$\beta_{0}^{+}$ & $\begin{array}{c}0.179 * * \\
(0.072)\end{array}$ & $\begin{array}{l}-0.099 \\
(0.171)\end{array}$ & $\begin{array}{c}0.076 \\
(0.109)\end{array}$ & $\begin{array}{c}0.314 * * * \\
(0.113)\end{array}$ & $\begin{array}{l}0.367^{*} \\
(0.189)\end{array}$ & $\begin{array}{c}0.059 \\
(0.135)\end{array}$ & $\begin{array}{c}0.254 * * * \\
(0.069)\end{array}$ & $\begin{array}{c}0.435^{* * *} \\
(0.115)\end{array}$ \\
\hline$\beta_{0}^{-}$ & $\begin{array}{c}0.500 * * * \\
(0.067)\end{array}$ & $\begin{array}{c}0.035 \\
(0.109)\end{array}$ & $\begin{array}{c}0.690 * * * \\
(0.110)\end{array}$ & $\begin{array}{c}0.338 * * * \\
(0.095)\end{array}$ & $\begin{array}{c}0.482^{* *} \\
(0.187)\end{array}$ & $\begin{array}{l}-0.015 \\
(0.078)\end{array}$ & $\begin{array}{c}0.507 * * * \\
(0.110)\end{array}$ & $\begin{array}{c}0.311 * * * \\
(0.081)\end{array}$ \\
\hline$\beta_{1}^{+}$ & $\begin{array}{c}0.095 \\
(0.082)\end{array}$ & $\begin{array}{l}-0.322 \\
(0.227)\end{array}$ & $\begin{array}{l}0.217^{*} \\
(0.117)\end{array}$ & $\begin{array}{c}0.135 \\
(0.118)\end{array}$ & $\begin{array}{c}0.289 * * \\
(0.117)\end{array}$ & $\begin{array}{l}-0.211 \\
(0.180)\end{array}$ & $\begin{array}{c}0.237 * * \\
(0.105)\end{array}$ & \\
\hline$\beta_{1}^{-}$ & $\begin{array}{c}0.131 \\
(0.093)\end{array}$ & $\begin{array}{c}0.559 * * * \\
(0.138)\end{array}$ & $\begin{array}{l}0.239^{*} \\
(0.127)\end{array}$ & $\begin{array}{l}-0.084 \\
(0.097)\end{array}$ & $\begin{array}{c}0.306^{* *} \\
(0.131)\end{array}$ & $\begin{array}{c}0.362 * * * \\
(0.113)\end{array}$ & $\begin{array}{l}-0.033 \\
(0.096)\end{array}$ & \\
\hline$\beta_{2}^{+}$ & & $\begin{array}{c}0.123 \\
(0.103)\end{array}$ & & & & & $\begin{array}{c}0.043 \\
(0.090)\end{array}$ & \\
\hline$\beta_{2}^{-}$ & & $\begin{array}{l}0.175^{*} \\
(0.097)\end{array}$ & & & & & $\begin{array}{c}-0.330 * * * \\
(0.098)\end{array}$ & \\
\hline$\beta_{3}^{+}$ & & & & & & & $\begin{array}{l}-0.128 \\
(0.090)\end{array}$ & \\
\hline$\beta_{3}^{-}$ & & & & & & & $\begin{array}{l}0.206^{*} \\
(0.117)\end{array}$ & \\
\hline$\theta^{+}$ & $\begin{array}{l}-0.161 \\
(0.156)\end{array}$ & $\begin{array}{l}-0.091 \\
(0.206)\end{array}$ & $\begin{array}{c}-0.269^{*} \\
(0.144)\end{array}$ & $\begin{array}{l}-0.285^{*} \\
(0.164)\end{array}$ & $\begin{array}{c}0.036 \\
(0.258)\end{array}$ & $\begin{array}{c}-0.329 * * * \\
(0.098)\end{array}$ & $\begin{array}{c}-0.641 * * * \\
(0.234)\end{array}$ & $\begin{array}{c}-0.241 * * * \\
(0.047)\end{array}$ \\
\hline$\theta^{-}$ & $\begin{array}{c}-0.398 * * * \\
(0.114)\end{array}$ & $\begin{array}{c}-1.098 * * * \\
(0.277)\end{array}$ & $\begin{array}{c}-0.834 * * * \\
(0.192)\end{array}$ & $\begin{array}{l}-0.205 \\
(0.165)\end{array}$ & $\begin{array}{l}-0.262^{*} \\
(0.157)\end{array}$ & $\begin{array}{c}-0.615 * * * \\
(0.213)\end{array}$ & $\begin{array}{l}-0.618^{*} \\
(0.319)\end{array}$ & $\begin{array}{c}-0.378 * * * \\
(0.084)\end{array}$ \\
\hline
\end{tabular}

The optimal lags of the asymmetric ECM are determined using the Schwarz criterion (maximum lags $=12$ ). The number in (.) under the coefficients is the standard deviation. Because it is impossible to eliminate the presence of correlated and heterogeneous variable in the residuals, the standard derivation was calculated using the Newey-West HAC covariance matrix estimation. ${ }^{* * *},{ }^{* *}$, and $*$ indicate that the coefficients are significant at the $1 \%, 5 \%$, and $10 \%$ levels.

To rigorously examine whether asymmetric adjustments exist in gasoline and diesel prices, a Wald coefficient test was conducted and the results are shown in Table 4. Long-term asymmetry exists if the test results can reject the null hypothesis of $\theta^{+}=\theta^{-}$. However, only two of the eight price variables rejected this null hypothesis (i.e., the gasoline prices in Japan and South Korea). In addition, the oil price impacts had significant asymmetric effects on all variables except for the gasoline price in Singapore and the diesel price in Taiwan. Furthermore, the gasoline and diesel prices in Japan and the diesel prices in Taiwan and South Korea were significantly autoregressive and asymmetric. A simultaneous test of $\alpha_{i}^{+}=\alpha_{i}^{-}$and $\beta_{i}^{+}=\beta_{i}^{-}$was conducted (the null hypothesis being short-term asymmetry), and the results showed that five of the eight prices significantly rejected the null hypothesis at $10 \%$ significance level.

In summary, price asymmetry exists if any hypothesis of symmetric adjustment is rejected (Chen et al., 2005). Table 4 shows that the gasoline and diesel prices were primarily asymmetric for short-term prices. A total of 17 of the 35 tests rejected the null hypothesis, with a rejection rate of approximately $48.57 \%$. With the exception of the gasoline price in Singapore, the other prices were confirmed to have undergone or to exhibit asymmetric adjustments, indicating that research on gasoline and diesel price dynamics should not overlook potential asymmetric characteristics. 
Table 4. Price asymmetry tests

\begin{tabular}{|c|c|c|c|c|c|c|c|c|}
\hline $\begin{array}{l}\text { Null } \\
\text { Hypothesis: }\end{array}$ & $\alpha_{1}^{+}=\alpha_{1}^{-}$ & $\alpha_{2}^{+}=\alpha_{2}^{-}$ & $\beta_{0}^{+}=\beta_{0}^{-}$ & $\beta_{1}^{+}=\beta_{1}^{-}$ & $\beta_{2}^{+}=\beta_{2}^{-}$ & $\beta_{3}^{+}=\beta_{3}^{-}$ & $\begin{array}{l}\text { Short-run } \\
\text { symmetry }\end{array}$ & $\theta^{+}=\theta^{-}$ \\
\hline \multicolumn{9}{|c|}{ Retail gasoline prices } \\
\hline Taiwan & 1.408 & & $7.709 * * *$ & 0.071 & & & $2.791 * *$ & 1.091 \\
\hline Japan & $5.876^{* *}$ & & 0.317 & $7.100 * * *$ & 0.090 & & 2.017 & $7.109^{*}$ \\
\hline South Korea & 1.688 & & $10.993 * * *$ & 0.013 & & & $4.043 * * *$ & $15.998 * * *$ \\
\hline Singapore & 0.005 & & 0.019 & 1.638 & & & 0.567 & 0.085 \\
\hline \multicolumn{9}{|c|}{ Retail diesel prices } \\
\hline Taiwan & $4.342 * *$ & & 0.124 & 0.006 & & & $5.566^{* * *}$ & 0.747 \\
\hline Japan & $6.849 * *$ & & 0.170 & $4.607 * *$ & & & $2.304 *$ & 1.052 \\
\hline South Korea & $0.400^{*}$ & & $3.354 *$ & 2.405 & $6.103 * *$ & $4.081 * *$ & $2.598 * *$ & 0.002 \\
\hline Singapore & 1.197 & 0.007 & $0.600 * *$ & & & & 0.777 & 1.596 \\
\hline
\end{tabular}

1. The numbers in this table are $F$ statistics. ***, **, and * indicate that the null hypothesis is rejected at the $1 \%$, $5 \%$, and $10 \%$ significance levels.

2. The null hypothesis of short-run symmetry are $\alpha_{i}^{+}=\alpha_{i}^{-}$and $\beta_{i}^{+}=\beta_{i}^{-}$for all $i$.

However, cumulative adjustment functions must be employed to explore the actual adjustment paths of gasoline and diesel prices in response to positive and negative oil price impacts. In the following analysis, $C_{i}^{+}$and $C_{i}^{-}$were defined as the cumulative adjustments during the $i^{\text {th }}$ period after oil prices were increased or reduced by $1 \%$, respectively, as shown below (Bettendorf et al., 2003; Borenstein et al., 1997; Fery \& Manera, 2007; Johnson, 2002):

$$
\begin{gathered}
C_{i}^{+}=C_{i-1}^{+}+\beta_{i}^{+}+\left\{\begin{array}{l}
\theta^{+}\left(C_{i-1}^{+}-\delta_{1}\right), \text { if } C_{i-1}^{+}-\delta_{1}>0 \\
\theta^{-}\left(C_{i-1}^{+}-\delta_{1}\right), \text { if } C_{i-1}^{+}-\delta_{1}<0
\end{array}\right. \\
+\left\{\begin{array}{l}
\sum_{j=1}^{m} \alpha_{j}^{+} \max \left\{C_{m-j}^{+}-C_{m-j-1}^{+}, 0\right\}, \text { if } C_{m-j}^{+}-C_{m-j-1}^{+}>0 \\
\sum_{j=1}^{m} \alpha_{j}^{-} \min \left\{C_{m-j}^{+}-C_{m-j-1}^{+}, 0\right\}, \text { if } C_{m-j}^{+}-C_{m-j-1}^{+}<0
\end{array}\right. \\
C_{i}^{-}=C_{i-1}^{-}+\beta_{i}^{-}+\left\{\begin{array}{l}
-\theta^{+}\left(C_{i-1}^{-}-\delta_{1}\right), \text { if }-\left(C_{i-1}^{-}-\delta_{1}\right)>0 \\
-\theta^{-}\left(C_{i-1}^{-}-\delta_{1}\right), \text { if }-\left(C_{i-1}^{-}-\delta_{1}\right)<0
\end{array}\right. \\
+\left\{\begin{array}{l}
\sum_{j=1}^{m} \alpha_{j}^{+} \max \left\{C_{m-j}^{-}-C_{m-j-1}^{-}, 0\right\}, \text { if } C_{m-j}^{-}-C_{m-j-1}^{-}>0 \\
\sum_{j=1}^{m} \alpha_{j}^{-} \min \left\{C_{m-j}^{-}-C_{m-j-1}^{-}, 0\right\}, \text { if } C_{m-j}^{-}-C_{m-j-1}^{-}<0
\end{array}\right.
\end{gathered}
$$

Table 5 shows the relative cumulative adjustments of retail gasoline and diesel prices responding to oil price impacts (i.e., $C_{i}^{+} / \delta_{1}$ and $C_{i}^{-} / \delta_{1}$, respectively). When $C_{i}^{+} / \delta_{1} \rightarrow 1$, adjustments to gasoline prices are completed at the $t+i^{\text {th }}$ period as oil prices increase by $1 \%$ at the $t^{\text {th }}$ period, and the $i^{\text {th }}$ period is the reaction time for gasoline prices to respond to positive oil price impacts. A significant difference in the reaction time for gasoline prices to respond to the positive and negative impacts of oil prices indicates reaction time asymmetry. Table 5 shows that when oil price impacts occurred, adjustments to the gasoline and diesel prices in Taiwan and Japan were completed within 2 to 3 months, whereas the adjustments in South Korea and Singapore required a longer reaction time (e.g., the gasoline and diesel prices in Singapore were not fully adjusted within eight months). In addition, the response of gasoline and diesel prices to positive oil price impacts did not necessarily require less reaction time, which was particularly true for gasoline prices in South Korea. Although retailers in an oligopoly have some power over pricing, government intervention behaviors appear to dominate the gasoline and diesel price adjustments of the four countries examined in this study. However, in Singapore, the gasoline and diesel prices exhibited a more obvious trend of rapid increases and slow decreases. Moreover, Johnson (2002) indicated that diesel is purchased primarily by those involved with large methods or tools of transportation; because of their frequent and high consumption amounts, diesel price adjustments are more immediate or rapid than gasoline price adjustments. Nevertheless, as shown in Table 5, only the prices in South Korea and Singapore supported this argument. 
Table 5. Cumulate relative responses

\begin{tabular}{|c|c|c|c|c|c|c|c|c|}
\hline & \multicolumn{8}{|c|}{ Period (i) } \\
\hline & Month 1 & Month 2 & Month 3 & Month 4 & Month 5 & Month 6 & Month 7 & Month 8 \\
\hline \multicolumn{9}{|c|}{ Taiwan-Retail Gasoline Price } \\
\hline$C_{i}^{+} / \delta_{1}$ & 0.30 & 1.05 & 1.11 & 1.11 & 1.10 & 1.08 & 1.07 & 1.05 \\
\hline$C_{i}^{-} / \delta_{1}$ & 0.83 & 1.04 & 1.11 & 1.12 & 1.10 & 1.08 & 1.07 & 1.06 \\
\hline \multicolumn{9}{|c|}{ Taiwan- Retail Diesel Price } \\
\hline$C_{i}^{+} / \delta_{1}$ & 0.46 & 0.63 & 0.72 & 0.74 & 0.80 & 0.81 & 0.85 & 0.87 \\
\hline$C_{i}^{-} / \delta_{1}$ & 0.60 & 0.75 & 0.79 & 0.80 & 0.85 & 0.86 & 0.89 & 0.90 \\
\hline \multicolumn{9}{|c|}{ Japan-Retail Gasoline Price } \\
\hline$C_{i}^{+} / \delta_{1}$ & -0.20 & 0.59 & 1.13 & 1.32 & 1.45 & 1.44 & 1.37 & 1.30 \\
\hline$C_{i}^{-} / \delta_{1}$ & 0.07 & 0.70 & 1.03 & 0.91 & 0.97 & 1.11 & 1.09 & 1.09 \\
\hline \multicolumn{9}{|c|}{ Japan-Retail Diesel Price } \\
\hline$C_{i}^{+} / \delta_{1}$ & 0.10 & 0.84 & 1.19 & 1.29 & 1.24 & 1.17 & 1.13 & 1.10 \\
\hline$C_{i}^{-} / \delta_{1}$ & -0.03 & 0.80 & 0.98 & 1.13 & 1.15 & 1.08 & 1.01 & 1.01 \\
\hline \multicolumn{9}{|c|}{ South Korea-Retail Gasoline Price } \\
\hline$C_{i}^{+} / \delta_{1}$ & 0.11 & 0.71 & 0.65 & 0.60 & 0.51 & 0.72 & 0.82 & 0.80 \\
\hline$C_{i}^{-} / \delta_{1}$ & 0.97 & 1.13 & 0.95 & 0.74 & 0.65 & 0.90 & 0.98 & 1.01 \\
\hline \multicolumn{9}{|c|}{ South Korea-Retail Diesel Price } \\
\hline$C_{i}^{+} / \delta_{1}$ & 0.35 & 1.35 & 1.00 & 0.95 & 0.98 & 1.00 & 1.01 & 1.00 \\
\hline$C_{i}^{-} / \delta_{1}$ & 0.70 & 1.08 & 1.15 & 1.19 & 1.08 & 1.01 & 1.00 & 1.00 \\
\hline \multicolumn{9}{|c|}{ Singapore-Retail Gasoline Price } \\
\hline$C_{i}^{+} / \delta_{1}$ & 0.40 & 0.70 & 0.76 & 0.80 & 0.84 & 0.87 & 0.89 & 0.91 \\
\hline$C_{i}^{-} / \delta_{1}$ & 0.43 & 0.53 & 0.62 & 0.69 & 0.74 & 0.79 & 0.83 & 0.86 \\
\hline \multicolumn{9}{|c|}{ Singapore-Retail Diesel Price } \\
\hline$C_{i}^{+} / \delta_{1}$ & 0.55 & 0.68 & 0.78 & 0.85 & 0.88 & 0.91 & 0.94 & 0.95 \\
\hline$C_{i}^{-} / \delta_{1}$ & 0.39 & 0.65 & 0.74 & 0.83 & 0.87 & 0.90 & 0.93 & 0.95 \\
\hline
\end{tabular}

\section{Conclusion}

Dramatic fluctuations in recent international oil prices have caused governments and the public to focus greater attention on adjustments to gasoline prices. Based on monthly data between 2004M1 and 2012M6, this study employed an asymmetric ECM to estimate the retail gasoline and diesel price adjustment models in Taiwan, Japan, South Korea, and Singapore. In this study, oil prices were considered the main cost of refining gasoline and diesel, and they had a significant long-term equilibrium relationship with gasoline and diesel prices. An examination of the dynamic adjustments of gasoline and diesel prices showed that asymmetric adjustments were common and that price asymmetry was primarily short-term. Despite the slight difference in the price adjustments in various countries and gasoline and diesel for automobile, the majority of the price adjustments were closer to the politico-economic asymmetry proposed by Kirchgassner and Kubler (1992) compared to the rockets and feathers trend indicated by numerous other studies. In other words, although the gasoline and diesel markets feature marked imperfect competition, government intervention appears to dominate the gasoline and diesel price adjustments in the four East Asian countries discussed in this study.

\section{Acknowledgements}

We wish to acknowledge the helpful comments of anonymous referees and financial support from the National Science Council of Taiwan (NSC 101-2410-H-431-004).

\section{References}

Al-Gudhea, S., Kenc, T., \& Dibooglu, S. (2007). Do Retail Gasoline Prices Rise More Readily than They Fall? A Threshold Cointegration Approach. Journal of Economics and Business, 59, 560-574. http://dx.doi.org/10.1016/j.jeconbus.2006.10.002

Bachmeier, L. J., \& Griffin, J. M. (2003). New Evidence on Asymmetric Gasoline Price Responses. Review of Economics and Statistics, 85, 772-776. http://dx.doi.org/10.1162/003465303322369902

Bacon, R. W. (1991). Rockets and Feathers: The Asymmetric Speed of Adjustment of U.K. Retail Gasoline Prices to 
Cost Changes. Energy Economics, 13, 211-218. http://dx.doi.org/10.1016/0140-9883(91)90022-R

Bettendorf, L., van der Geest, S. A., \& Varkevisser M. (2003). Price Asymmetry in the Dutch Retail Gasoline Market. Energy Economics, 25, 669-689. http://dx.doi.org/10.1016/S0140-9883(03)00035-5

Borenstein, S., Cameron, A. C., \& Gilbert, R. (1997). Do Gasoline Prices Respond Asymmetrically To Crude Oil Price Changes? The Quarterly Journal of Economics, 305-339.

Chen, L. H., Finney, M., \& Lai, K. S. (2005). A Threshold Cointegration Analysis of Asymmetric Price Transmission from Crude Oil to Gasoline Prices. Economics Letters, 89, 233-239. http://dx.doi.org/10.1016/j.econlet.2005.05.037

Chou, K. W. (2012). Price Adjustment in Taiwan Retail Gasoline Market. International Journal of Economics and Finance, 4(7), 132-140. http://dx.doi.org/10.5539/ijef.v4n7p132

Engle, R. F., \& Granger, C. W. J. (1987). Co-Integration and Error Correction: Representation, Estimation, and Testing. Econometrica, 55, 251-276.

Frey, G., \& Manera, M. (2007). Econometric Models of Asymmetric Price Transmission. Journal of Economic Surveys, 21, 349-415.

Galeotti, M., Lanza, A., \& Manera, M. (2003). Rockets and Feathers Revisited: An International Comparison on $\begin{array}{lllll}\text { European } \quad \text { Gasoline } & \text { Markets. Energy }\end{array}$ http://dx.doi.org/10.1016/S0140-9883(02)00102-0

Godby, R., Lintner, A. M., \& Wandschneider, T. S. B. (2000). Testing for Symmetric Pricing in the Canada Retail Gasoline Market. Energy Economics, 22, 349-368. http://dx.doi.org/10.1016/S0140-9883(99)00030-4

Granger, C. W. J., \& Lee, T. H. (1989). Investigation of Production, Sales and Inventory Relationships Using Multicointegration and Non-Symmetric Error Correction Models. Journal of Applied Economics, 4, S145-S159. http://dx.doi.org/10.1002/jae.3950040508

Johnson, R. N. (2002). Search Costs, Lags and Prices at the Pump. Review of Industrial Organization, 20, 33-50.

Karrenbrock, J. D. (1991). The Behavior of Retail Gasoline Prices: Symmetric or Not? Federal Reserve Bank of St. Louis, 73, 19-29.

Kirchgassner, G., \& Kubler, K. (1992). Symmetric or Asymmetric Price Adjustment in the Oil Market: An Empirical Analysis of the Relations between International and Domestic Prices in the Federal Republic of Germany 1972-1989. Energy Economics, 14, 171-185.

Manning, D. N. (1991). Petrol Prices, Oil Price Rises and Oil Price Falls: Some Evidence for the UK since 1972. Applied Economics, 23, 1535-1541.

Newey, W. K., \& West, K. (1987). A Simple Positive Semi-Definite Heteroskedasticity and Autocorrelation Consistent Covariance Matrix. Econometrica, 55, 703-708.

Radchenko, S. (2005). Oil Price Volatility and the Asymmetric Response of Gasoline Prices to Oil Price Increases and Decreases. Energy Economics, 27, 708-730. http://dx.doi.org/10.1016/j.eneco.2005.06.001

Radchenko, S., \& Shapiro, D. (2011). Anticipated and Unanticipated Effects of Crude Oil Prices and Gasoline Inventory Changes on Gasoline Prices. Energy Economics, 33, 758-769. http://dx.doi.org/10.1016/j.eneco.201.01.002

Tappata, M. (2009). Rockets and Feathers: Understanding Asymmetric Pricing. RAND Journal of Economics, 40, 673-687. http://dx.doi.org/10.1111/j.1756-2171.2009.00084.x

Verlinda, J. A. (2008). Do Rockets Rise Faster and Feathers Fall Slower in an Atmosphere of Local Market Power? Evidence from the Retail Gasoline Market. The Journal of Industrial Economics, 56, 581-612. http://dx.doi.org/10.1111/j.1467-6451.2008.00351.x

Wu, J. H., Huang, Y. L., \& Liu, C. C. (2011). Effect of Floating Price Policy: An Application of System Dynamics on Oil Market after Liberalization. Energy Policy, 39, 4235-4252. http://dx.doi.org/10.1016/j.enpol.2011.04.039 